\title{
The match between students' lesson perceptions and preferences: relations with student characteristics and the importance of motivation
}

Citation for published version (APA):

Konings, K. D., Brand-Gruwel, S., \& van Merrienboer, J. J. G. (2011). The match between students' lesson perceptions and preferences: relations with student characteristics and the importance of motivation. Educational Research, 53(4), 439-457. https://doi.org/10.1080/00131881.2011.625155

Document status and date:

Published: 01/01/2011

DOI:

10.1080/00131881.2011.625155

Document Version:

Publisher's PDF, also known as Version of record

Document license:

Taverne

Please check the document version of this publication:

- A submitted manuscript is the version of the article upon submission and before peer-review. There can be important differences between the submitted version and the official published version of record.

People interested in the research are advised to contact the author for the final version of the publication, or visit the DOI to the publisher's website.

- The final author version and the galley proof are versions of the publication after peer review.

- The final published version features the final layout of the paper including the volume, issue and page numbers.

Link to publication

\footnotetext{
General rights rights.

- You may freely distribute the URL identifying the publication in the public portal. please follow below link for the End User Agreement:

www.umlib.nl/taverne-license

Take down policy

If you believe that this document breaches copyright please contact us at:

repository@maastrichtuniversity.nl

providing details and we will investigate your claim.
}

Copyright and moral rights for the publications made accessible in the public portal are retained by the authors and/or other copyright owners and it is a condition of accessing publications that users recognise and abide by the legal requirements associated with these

- Users may download and print one copy of any publication from the public portal for the purpose of private study or research.

- You may not further distribute the material or use it for any profit-making activity or commercial gain

If the publication is distributed under the terms of Article 25fa of the Dutch Copyright Act, indicated by the "Taverne" license above, 


\title{
The match between students' lesson perceptions and preferences: relations with student characteristics and the importance of motivation
}

\author{
Karen D. Könings , Saskia Brand-Gruwel \& Jeroen J.G. van Merriënboer
}

To cite this article: Karen D. Könings , Saskia Brand-Gruwel \& Jeroen J.G. van Merriënboer (2011) The match between students' lesson perceptions and preferences: relations with student characteristics and the importance of motivation, Educational Research, 53:4, 439-457, DOI: 10.1080/00131881.2011.625155

To link to this article: https://doi.org/10.1080/00131881.2011.625155

曲 Published online: 02 Nov 2011.

Submit your article to this journal $\sqsubset$

山ll Article views: 1794

View related articles

Citing articles: 2 View citing articles 지 


\title{
The match between students' lesson perceptions and preferences: relations with student characteristics and the importance of motivation
}

\author{
Karen D. Könings ${ }^{\mathrm{a} *}$, Saskia Brand-Gruwel ${ }^{\mathrm{b}}$ and Jeroen J.G. van Merriënboer ${ }^{\mathrm{a}}$ \\ ${ }^{a}$ Department of Educational Development \& Research and Research Graduate School of Health \\ Professions Education, Maastricht University, Maastricht, The Netherlands, ${ }^{b}$ Centre for \\ Learning Sciences and Technologies, Open University of the Netherlands, Heerlen, \\ The Netherlands
}

(Received 1 February 2011; final version received 9 August 2011)

Background: The match between students' perceptions of a learning environment and their preferences about its design influences students' learning behaviour and by consequence the effectiveness of education. Therefore, the students' perspective deserves a more prominent place in the educational design process. Having an adequate picture of the match between students' perceptions and preferences is needed for teachers/educational designers to account for students' perspectives while designing education. As perception-preference match is likely to differ between students, establishing correlates to it would provide valuable information. Students' perceptions are known to relate to several student characteristics; this study extends our understanding to its relations with perception-preference match.

Purpose: This study aims to investigate the degree to which students' perceptions of lessons match with their preferences about different characteristics of modern education. Additionally, it is aimed to determine the most prominent relationships between perception-preference match and learning-related student characteristics.

Sample: The sample consisted of 1146 10th-grade high school students (mean age $=16$ years) from five secondary schools in the Netherlands. As data collection took place during normal school hours, the response rate was $100 \%$, comprising all students that were at school on the day of data collection.

Design and methods: To measure students' perceptions of the lessons and their preferences about its instructional design, students completed the Inventory of Perceived Study Environment Extended, being composed of eight scales about central characteristics of modern education. The Inventory of Learning Styles was administered to measure learning-related student characteristics: cognitive processing strategies, regulation strategies, motivational orientations, conceptions about learning and affective processing strategies. To answer the research questions, paired $t$-tests and multiple regression analyses were conducted.

Results: Findings showed low perception-preference matches on fascinating contents, clarity of goals and student autonomy. Students preferred these characteristics being more represented in their lessons than they actually perceived them. Perception-preference match was predominantly related to students' motivation and affective state: a personally interested motivational orientation related to better perception-preference match, whereas motivation/ concentration problems related to worse matches. These relations did not give

*Corresponding author. Email: Kd.Konings@maastrichtuniversity.nl 
indications about causality, but based on the literature a bidirectional relation is supposed.

Conclusion: This study shows that students' perception-preference match gives clear indications for which aspects of lessons could be improved. As students consider almost all characteristics of modern education as desirable, meeting students' preferences could contribute to more effective education. Additionally, the perception-preference match relates to students' motivation and affective strategies. Improving education by accounting for the match between students' perceptions and preferences of education is likely to improve motivation as well as having a significant effect on the quality of education.

Keywords: student experience; instructional design; alignment; motivation; user satisfaction

\section{Introduction}

Educational designers and teachers focus lots of effort on designing instructional methods that provide students optimal conditions to learn. However, only their own knowledge and professional experiences are incorporated. Students are usually not involved in the educational design process (Cook-Sather 2001), and designers and teachers have only limited insight in students' views on it (e.g. Kershner and Pointon 2000). Instruction that is meant to be appropriate for students will be most effective if it is actually perceived by them as appropriate (Elen and Lowyck 1999; Norman 1986, 1988). Therefore, the main goal of the current study is to investigate the degree to which student perceptions of their instruction/lessons match with their preferences. This question deserves a more prominent place in the educational design process, because it is known that students' perceptions of instruction are very important for its effectiveness in terms of learning results (Doyle 1977; Elen and Lowyck 1999; Entwistle and Tait 1990).

The first goal of this study is to investigate the degree of correspondence between students' perceptions and their preferences (i.e. perception-preference match) with respect to different characteristics of modern education, like the degree of student autonomy or the clarity of learning goals. Perception-preference match, however, is an individual adjustment of the degree to which instruction matches one's needs and preferences and this is likely to vary depending on students' characteristics (Eccles et al. 1993). Therefore, the second goal of this study is to learn more about relationships between perception-preference match and student characteristics.

\section{Educational design and the student's perspective}

According to the Combination-Of-Perspective model, information on how education is experienced by students should provide teachers and educational designers with feedback on their work (Könings, Brand-Gruwel, and Van Merriënboer 2005). It provides teachers with input they can use to optimise their lessons and should ultimately help designers to incorporate this user (i.e. student) knowledge in their instructional designs. Markopoulos and Bekker (2003) even argued that an educational design should be driven by knowledge of the students, and that they should not only be involved as users, testers and informants but as real design partners. It is of great value to determine explicitly how students perceive their education, especially because student interpretations of the environment are not easily predictable for teachers and designers (Donaldson 1978; Kershner and Pointon 2000). 
Although the importance of students' views is acknowledged (Burke 2007), it is not yet incorporated in designing daily teaching practices (Cook-Sather 2001). It is important to change this way of working, since research pointed out that not the characteristics of the instruction itself, but foremost students' perceptions of the instruction determine the nature and quality of their learning processes and, eventually, the effectiveness of instruction (Elen and Lowyck 1999; Entwistle and Tait 1990). If students' perceptions do not match with the original intentions of the teacher, the instruction is likely not to reach its goals. This fits within the cognitive mediational tradition (Doyle 1977), which stresses that instructional interventions do not directly influence student learning. The learning effects are mediated by students' perceptions and interpretations of the learning environment. Additionally, students use only those instructional elements that are in congruence with their learning preferences and match well with their habitual way of learning (Vermetten, Vermunt, and Lodewijks 2002). By consequence, more knowledge about the match between students' perceptions and preferences on instruction is of utmost importance. If there is a bad match, students are likely to choose their own ways of learning, instead of behaving in agreement with the instructional design (Vermetten, Vermunt, and Lodewijks 2002). Additionally, learning arrangements that do not match students' needs are likely to have negative consequences on their motivation and engagement (Eccles et al. 1993), cause problems such as poor grades, misconduct and poor mental health (Roeser, Eccles, and Sameroff 2000), and it may end in students' disengagement and drop-out of school (Hijzen, Boekaerts, and Vedder 2007; Smyth and Fasoli 2007). Thus, both the students and the educational setting would benefit from an optimal match between students' needs or preferences and their perceptions of the offered instruction. As an implication, students' criticisms and points of dissatisfaction (i.e. bad perception-preference match) have to be taken very seriously.

Taken together, exploring the perception-preference match as experienced by the students could offer insight and feedback about what is really going on in the class. Therefore, our first research question focuses on the degree to which high school students' perceptions of their (innovative) learning environment match with their preferences about its instructional design.

\section{Individual differences between students}

When listening to students and investigating their perceptions, preferences and the match between both, it should be noticed that their reports are personal and varied, even if they follow the same lessons. This variation might be related to students' varying needs and expectations of a learning environment, and dissimilar values and norms used by the students to reflect on it (Levy, den Brok, Wubbels, and Brekelmans 2003). Another source of variation in student reports is provided by the result of an interaction between internal, learning-related characteristics (metacognitive instructional knowledge) and external, environment-related characteristics of the education as it is offered to students (Luyten, Lowyck, and Tuerlinckx 2001). Relevant internal learning-related variables described in the literature include: (1) cognitive processing strategies, (2) regulation strategies, (3) motivational orientations, (4) conceptions about learning, and (5) affective processing strategies (Vermunt and Vermetten 2004). For each of these learning-related student characteristics there is evidence for a relation with student perceptions and/or preferences. 
First, students differ in their habits for using different kinds of cognitive processing strategies (i.e. cognitive activities that students use to process learning contents), which are likely to be related to the perceptions of the learning environment (e.g. Entwisle and Ramsden 1983; Entwistle and Tait 1990; Trigwell and Prosser 1991). Students who use deep processing strategies perceive the environment as more personalised, more strongly encouraging active learning and requiring more use of inquiry skills than students using stepwise processing strategies (Dart et al. 1999). Cognitive processing strategies are also related to preferences about the learning environment: students prefer an environment that supports their habitual way of learning (Entwistle and Tait 1990).

Second, the use of regulation strategies varies among students. In the way students regulate and steer their own learning process, they can regulate and manage their own learning process themselves, or rely heavily on the teacher or the environment for regulation, or even experience a complete lack of regulation during learning (Vermunt 1998). Students, who use self-regulatory strategies, actively manage their environment, adapt to it and change the environment to match better with their preferences and needs (Pintrich and Schauben 1992). These regulation strategies might lead to a better match between students' perceptions and preferences in a learning environment.

Third, students' motivational orientations (i.e. personal goals or motives students have for learning and going to school) seem relevant: changes in motivation can be explained by changing experiences of the lessons during a school year (Bong 2005). Learning environments that badly match with students' needs (i.e. bad perceptionpreference match) are likely to have negative consequences on students' motivation and engagement (e.g. Eccles et al. 1993), which in turns leads to inferior school performance (Schwinger, Steinmayr and Spinath 2009; Steinmayr and Spinath 2009). When students experience their educational needs (e.g. self-determination) as being neglected or frustrated, they even become vulnerable for dropping out of school (Hardre and Reeve 2003), which can be considered the most serious loss of motivation for learning.

Fourth, students' conceptions about learning and what constitutes learning relate to their perceptions of a learning environment (e.g. Dart et al. 2000). Conceptions influence perceptions as they can be seen as lenses through which people perceive and interpret the world (Pratt 1992). Tsai (2000) reported relationships between conceptions of knowledge and students' perceptions of instruction, as well as their preferences about how to learn: students with constructivist-oriented beliefs prefer environments in which knowledge construction has a prominent place. These students also perceive the environment differently, as they better understand the complexity of the offered environment and the learning opportunities they have in it (Campbell et al. 2001). Moreover, students' conceptions or epistemological beliefs indirectly influence learning approaches, as they are clearly related to the perceptions of the environment (Ozkal et al. 2009). Since both perceptions and preferences relate to conceptions about learning, perception-preference match may also relate to students' conceptions.

Fifth and last, affective processing strategies might also be related to students' perspectives on learning (Vermunt and Vermetten 2004). Affect refers to emotions and affective states, which may influence students' learning processes. Students' perceptions of teaching are related to the affective value of school: positive perceptions contribute to liking school and enthusiasm to participate in learning 
activities (Ireson and Hallam 2005). Enthusiasm and positivism about school are only possible if the perceptions match with students' preferences and, thus, a relation between affective processing strategies and perception-preference match is hypothesised in our study.

In sum, various studies have shown that different learning-related student characteristics are related in some way to student perceptions and/or preferences. However, they have all been studied separately, not in coherence with each other and the relations with perception-preference match is underexposed. The current study investigates which learning-related student characteristics are related most strongly to perceptionpreference match. Based on the literature, it can be hypothesised that motivational orientation will be strongly related to perception-preference match (as these effects are described already in fair detail), but there are limited indications to define a hierarchy of importance of variables beforehand. For getting a clearer view, we will include all mentioned learning-related student characteristics in one study.

Taken together, the current study answers two research questions:

(1) To what degree do students' perceptions of their learning environment match with their preferences about different aspects of modern education? As modern education is based on principles of cognitive psychology and constructivism, the focus will be on students' perception-preference match with respect to several characteristics of modern education.

(2) How does the degree of match between students' perceptions and preferences relate to learning-related characteristics, in particular, cognitive processing strategies, regulation strategies, motivational orientations, conceptions about learning and affective processing strategies?

\section{Method}

\section{Participants}

The sample consisted of 1146 students of five schools for secondary education in the Netherlands. All 10th graders (mean age $=16.32$ years, $\mathrm{SD}=0.60$ ) of these schools participated in the study. They were following either senior general secondary education $(47.2 \%)$ or pre-university education $(52.8 \%)$.

The participating schools in this study were located in the south of the Netherlands. The achievement level of the participating schools on the general examination indicates that they are representative of schools in the Netherlands, with one school at the senior general education level scoring greatly above the national average and two schools at the pre-university level scoring slightly above the average (Onderwijsinspectie [Dutch Inspection of Education] 2006).

\section{Materials}

\section{The learning environment}

The context of this study is a nationwide innovation in Dutch secondary education called the Second Phase (Ministerie van Onderwijs, Cultuur, en Wetenschap [Dutch Ministry of Education, Culture, and Science], n.d.; Stuurgroep Profiel Tweede Fase Voortgezet Onderwijs [Steering Committee for the Profile for the Second Stage of Secondary Education] 1995). The Second Phase requires students independently to 
acquire skills and knowledge to better prepare them for higher professional education and university. Students learn in a self-directed way with ample opportunities for collaborative learning. There is more room for individual differences than in the traditional educational system, and teachers have to take these differences into account. The teacher's role is more like that of a coach and less like that of an instructor, which creates more opportunities for interaction between students and the teacher. The learning process is not only directed to knowledge acquisition but also to the selection and processing of the vast amounts of information available today. In addition, the coherence between knowledge and skills and the application of knowledge in subjectmatter domains are emphasised. To summarise, the instructional design of the Second Phase includes all characteristics of a powerful learning environment.

\section{Inventory of Perceived Study Environment Extended (IPSEE)}

The IPSEE (Könings et al. 2008) measures students' perceptions of a particular learning environment and their preferences about its design. The perceptionpreference match pertains to the discrepancy between perception scores and preference scores. The IPSEE consists of 67 items. Thirty-one of these items originate from the Inventory of Perceived Study Environment (Wierstra et al. 1999; Picarelli et al. 2006). To measure the characteristics of powerful learning environments as described by Könings, Brand-Gruwel, and Van Merriënboer (2005) more completely, another 36 items were constructed.

The items of the IPSEE cover eight scales (Table 1) that are considered as central characteristics of modern education. The scale fascinating contents contains items about the extent to which the learning contents are interesting, challenging and personally relevant for the students. The scale productive learning indicates little emphasis on sole reproduction of learning contents but rather on an active process of making sense of the subject matter. The scale integration concerns integration of newly acquired knowledge with prior knowledge, of different subject matter domains, and of knowledge and skills. The scale student autonomy measures attention paid to students' self-directedness with regard to content of learning, way of learning and planning of time. The scale interaction incorporates collaboration with peers and interaction with the teacher. The scale differentiation inquires opportunities for students to choose and perform different learning tasks, solve problems in different ways, and use different learning materials. The scale clarity of goals includes items about the clarity of instructional goals and task demands. The scale personalisation measures the availability of support from teachers.

A sample item of each scale is included in Table 1. All items contain a statement about one of the characteristics of the learning environment and two questions, one related to the perceptions of a characteristic and one related to its desirability, as in the following example:

Students can decide for themselves how they wish to learn during the course.

(a) This happens.

(b) I would like this to happen.

The questions are answered on a 6-point scale, ranging from totally disagree $($ score $=1)$ to totally agree $($ score $=6)$. Scores on question A indicate students' perceptions and scores on question B indicate students' preferences. The discrepancy 


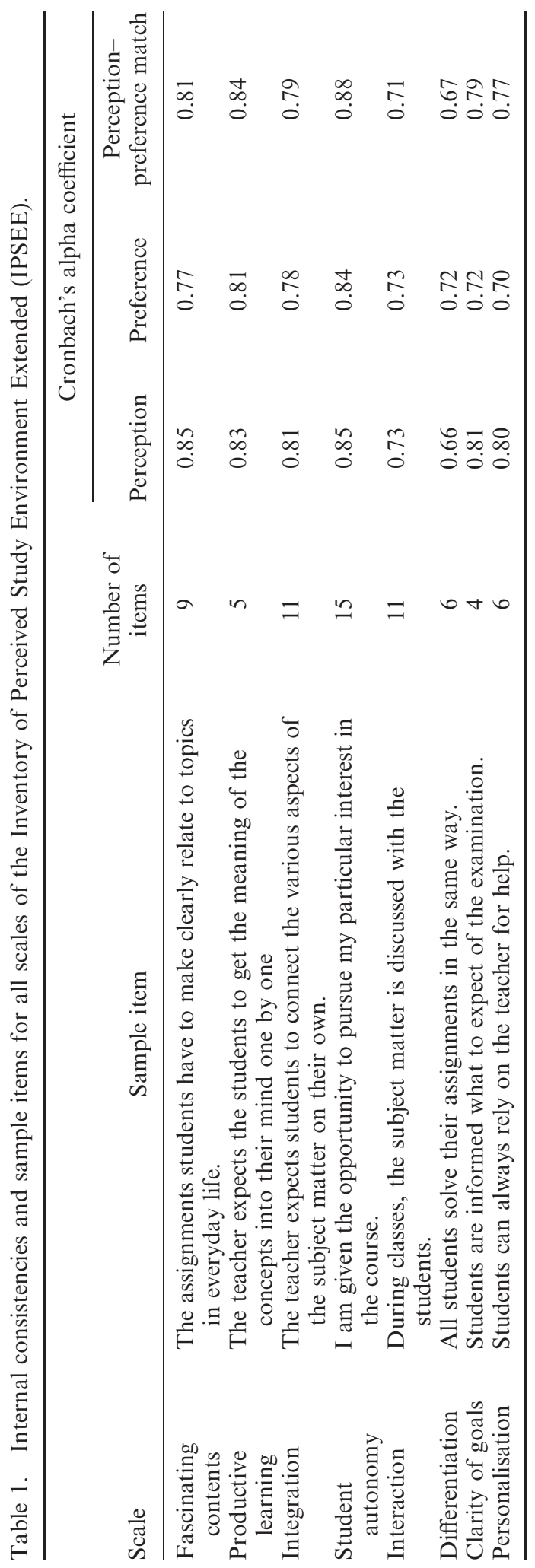


(i.e. absolute difference) between the scores on A and B refers to the perceptionpreference match with respect to the education offered (Wierstra et al. 1999). Discrepancy scores range from 0 , indicating a good perception-preference match, to 5 what indicates an inferior perception-preference match. So, higher discrepancy scores refer to low match. For reaching conceptual congruence between the numerical scores and the meaning of the degree of match, discrepancy scores are recoded so that a score of 0 indicates lowest match (i.e. minimum) and the score of 5 refers to the highest match (i.e. maximum). Match scores are computed as 5-discrepancy score.

Internal consistencies of the IPSEE scales are presented in Table 1. All Cronbach's alpha coefficients were above 0.70, except coefficients for the scale differentiation, which were above 0.65 . They were all acceptable. Additional psychometric analyses have shown that there is no collinearity between the scales of the IPSEE (Könings et al. 2008).

\section{Inventory of Learning Styles for Secondary Education (ILS-SE)}

This questionnaire (Vermunt 1992; Vermunt, Bouhuijs, and Picarelli 2003) measures learning-related characteristics on the basis of the usual way of learning of secondary school students. The ILS-SE consists of 100 items divided in five clusters: (1) processing strategies (cognitive activities that students use to process learning contents), (2) regulation strategies (the way students regulate their own learning process), (3) motivational orientations (personal goals or motives students have for learning and going to school), (4) conceptions of learning (mental models about learning), and (5) affective processing strategies (emotional aspects of learning). Each of the five clusters contains several scales, which are presented in Table 2.

For each item, students rate the degree to which that particular statement corresponds to their own learning on a 5-point scale. Information about internal consistencies of the scales is included in Table 2; all Cronbach's alpha coefficients were acceptable. For four scales, the coefficients were above 0.60 ; for the other scales the coefficients were above 0.70 . In addition to satisfactory internal consistencies, independency measures of the scales of ILS-SE have shown no statistical objections to considering the 16 scales separately (Könings et al. 2008; Picarelli et al. 2006).

\section{Procedure}

The participants filled out the IPSEE and the ILS-SE during regular school hours. Before completing the questionnaires, students were instructed about the goal and the contents of the questionnaires and about the scoring method. The IPSEE took between 30 and 40 minutes to complete; the ILS-SE took between 20 and 30 minutes to complete. Students voluntarily participated in this study. As data collection took place during regular school hours, the response rate was $100 \%$. Data collection was guided by the researcher, ensuring the students that their answers are handled confidentially and do not have any negative consequences to them.

\section{Data analysis}

For computing mean scores for each scale of the IPSEE, maximally $25 \%$ of missing values are accepted. So, if at least $75 \%$ of the items at scale level were filled out, these items were used to compute the mean score. Paired-samples $t$-tests were used to test 


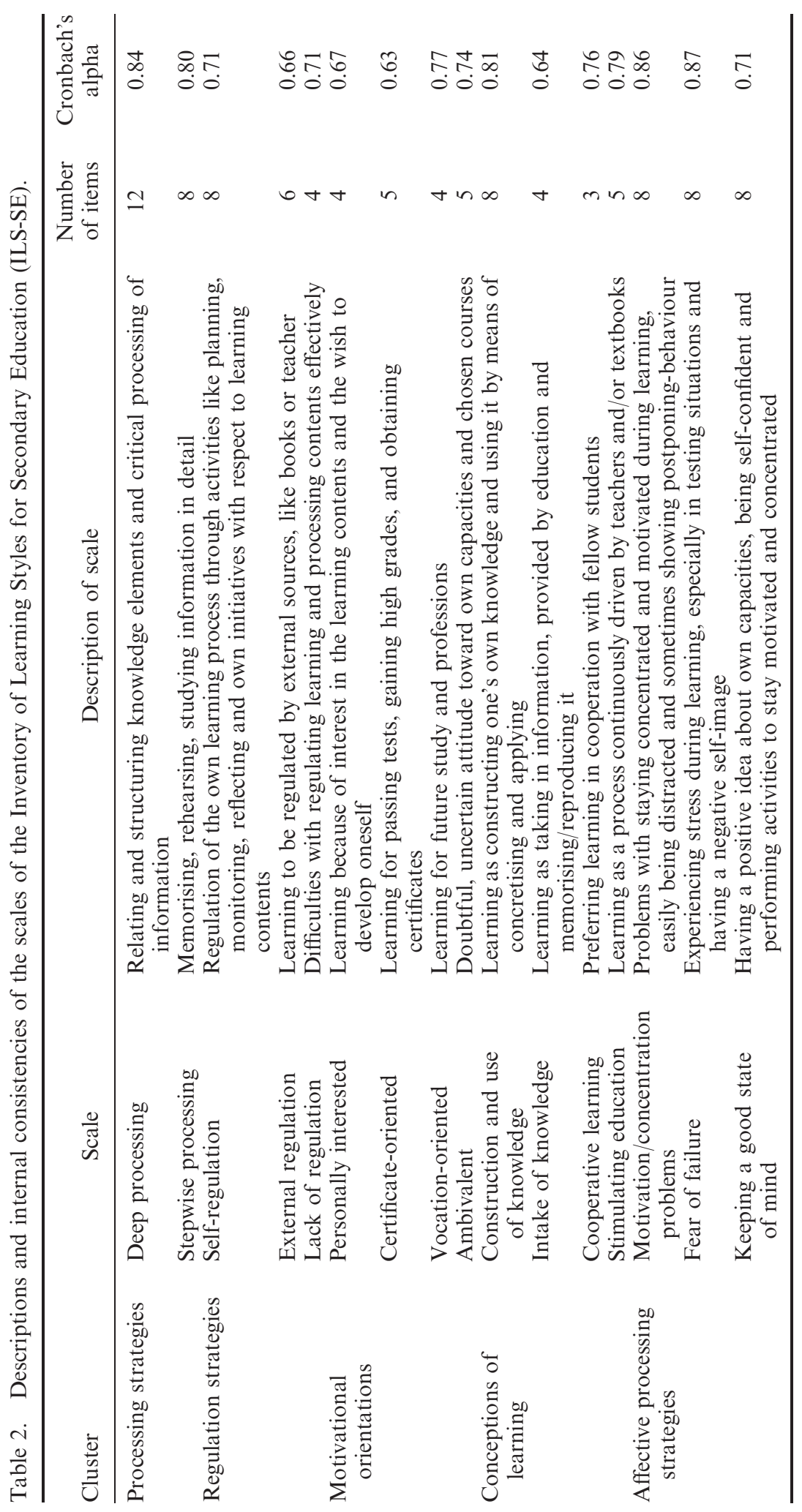


whether discrepancies between perceptions and preferences - indicating perceptionpreference match - were significant. Backward multiple regression analyses were conducted to investigate relations between perception-preference match scores and learningrelated student characteristics. Separate analyses were computed for the match scores of each of the IPSEE scales, including the particular IPSEE scale as a dependent variable and all ILS-SE scales as independent variables. Because of the large sample size in this study and the number of conducted analyses (increasing risk of type I errors), in the following section only results are reported, which are significant at a level of $p<0.01$.

\section{Results}

\section{Perception-preference match, perceptions and preferences}

Figure 1 presents the means of the perception and preference scores of the different scales of the IPSEE. By looking at the discrepancy between the perception bar and the preference bar, the perception-preference match can be deduced.

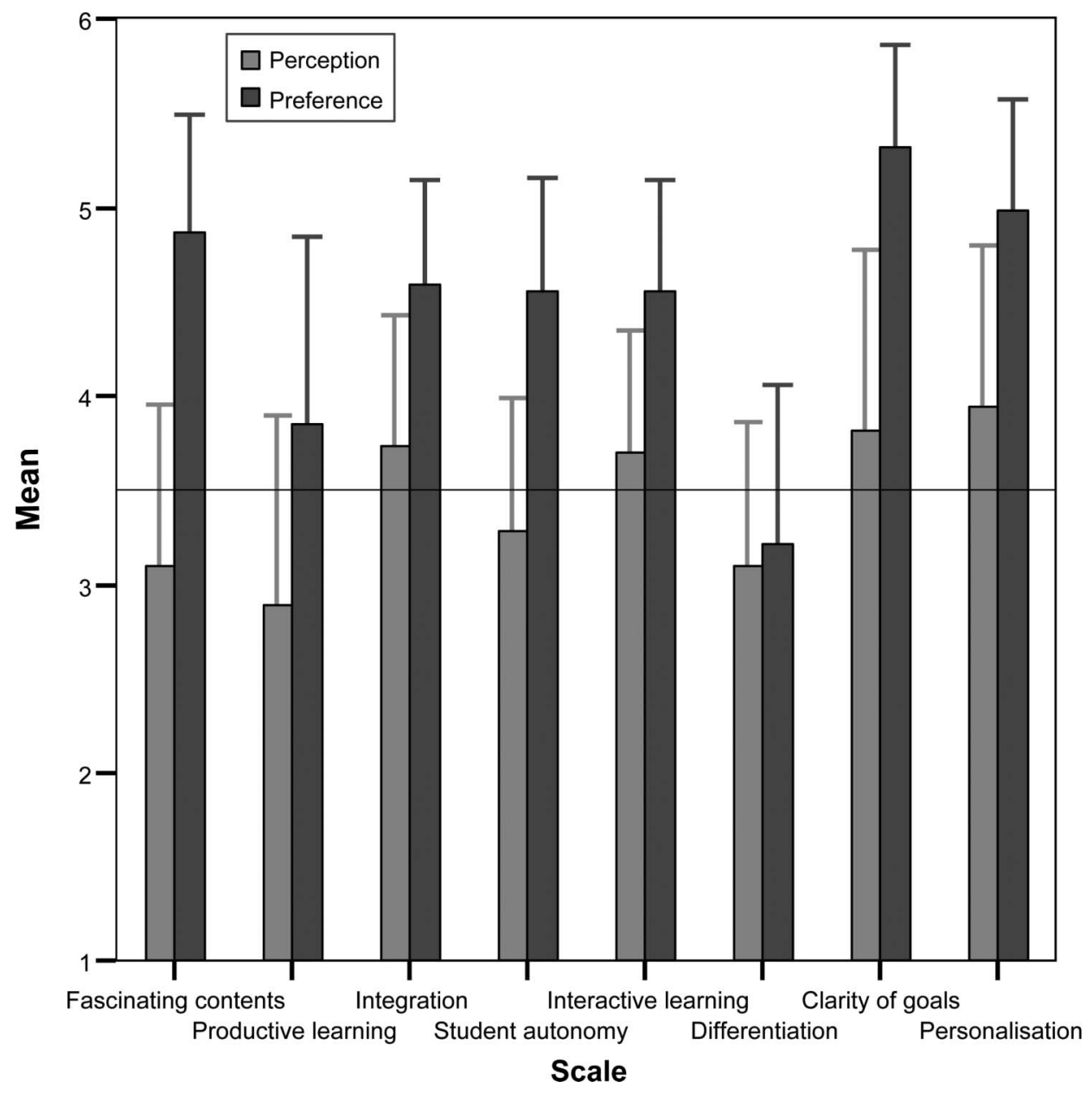

Figure 1. Mean scores and standard deviations of the perceived and preferred learning environment. 


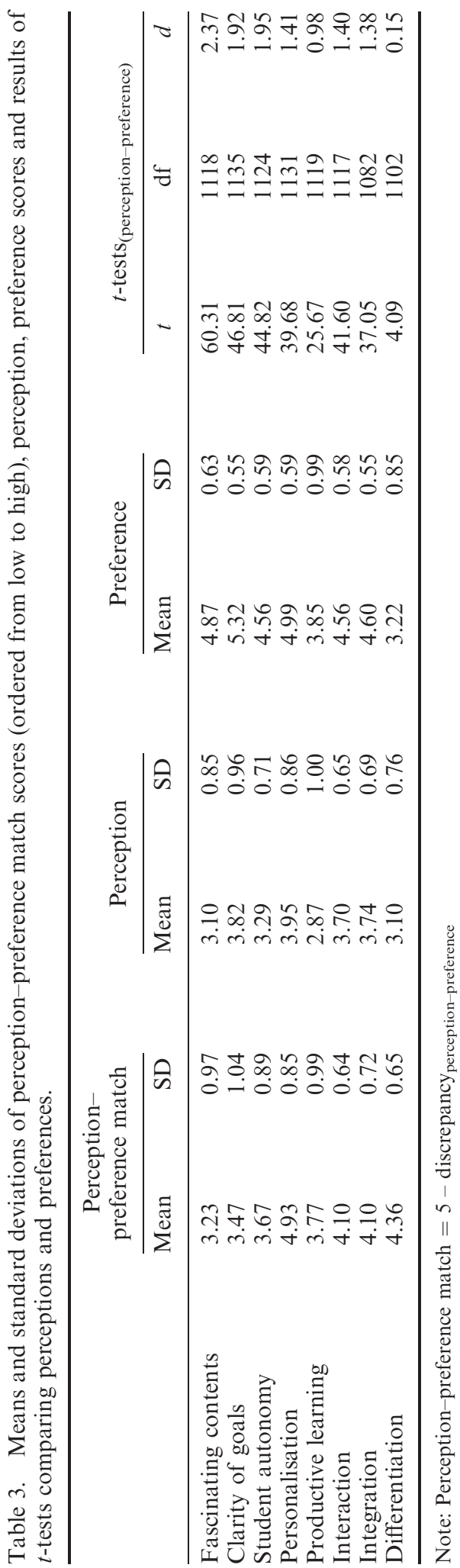


The more both scores differ, the poorer the perception-preference match (e.g. fascinating contents). The more both scores correspond, the better the perceptionpreference match (e.g. integration). Although the size of the discrepancy differs among scales, paired $t$-tests showed that for all scales perception scores differed significantly from preference scores (Table 3 ). Effect sizes were large ( $d$ between 0.98 and 2.37) for all but one scale. There was only a small effect on the scale differentiation $(d=0.15)$. Perception scores were always lower than preference scores $(p<0.01)$, indicating that students prefer a more powerful environment than they actually perceive. Table 3 presents the descriptive statistics of the perceptionpreference match scores, together with the perception and preference scores. It can be seen from the table that perception-preference match was worst for fascinating contents, clarity of learning goals and student autonomy.

Furthermore, one-sample $t$-tests showed that on four of eight scales perception scores were significantly higher than the neutral score of $3.5(p<0.01)$, indicating that students perceived these characteristics of modern education to be present in their actual learning environment: integration, interaction, clarity of goals and personalisation as higher than neutral ( $d$, respectively, $0.34,0.30,0.33$ and 0.52 ). However, perception scores were lower than 3.5 on half of the measured aspects of the environment: fascinating contents, productive learning, student autonomy and differentiation ( $d$, respectively, $0.47,0.61,0.30$ and 0.53$)$. Analyses on the preference scores showed that on seven of the eight scales preference scores were significantly higher than 3.5 ( $p<0.01, d$ between 0.35 and 3.31), which means that students clearly preferred most of the characteristics of modern education. As an exception, the preference about differentiation was significantly lower than the neutral score $(p<0.01, d=0.33)$.

\section{Perception-preference match scores and learning-related student characteristics}

Table 4 presents the results of the multiple regression analyses investigating the relations between perception-preference match scores and learning-related student characteristics, separately per IPSEE scale. Learning-related characteristics explained on average $8 \%$ of the variance in perception-preferences match on the different scales, ranging from $4 \%$ for the scale integration to $15 \%$ for fascinating contents. These percentages are rather low and beta weights are also relatively low, but from the table it can be seen that several student characteristics were frequently related to perception-preference match (i.e. on more than half of the IPSEE scales). These student characteristics will be described in more detail.

Perception-preference match scores were negatively related to displaying motivation/concentration problems. The more motivation/concentration problems were reported by students, the worse their perception-preference match scores for the scales fascinating contents, student autonomy, productive learning, interaction, integration and differentiation. In contrast, a personally interested motivational orientation was positively related to better perception-preference match on fascinating contents, clarity of goals, student autonomy, productive learning, personalisation and differentiation.

Strikingly, perception-preference match related most frequently to a motivational and an affective subscale: a personally interested motivational orientation contributes to better perception-preference match, whereas motivation/concentration problems contribute to inferior perception-preference match. Since match 
Table 4. Significant regression weights $(p<0.01)$ of variables predicting perceptionpreference match.

\begin{tabular}{lclrrr}
\hline Dependent variable & $R^{2}$ & \multicolumn{1}{c}{ Independent variable(s) } & $B$ & SE $B$ & \multicolumn{1}{c}{$\beta$} \\
\hline Fascinating contents & 0.15 & Motivation/concentration problems & -0.28 & 0.03 & -0.24 \\
& & Personally interested & 0.28 & 0.04 & 0.20 \\
& & Lack of regulation & -0.09 & 0.03 & -0.08 \\
Productive learning & 0.09 & Motivation/concentration problems & -0.20 & 0.04 & -0.17 \\
& & Personally interested & 0.25 & 0.04 & 0.18 \\
& & Keeping a good state of mind & -0.13 & 0.04 & -0.09 \\
Integration & \multirow{2}{*}{0.04} & Ambivalent & -0.11 & 0.03 & -0.11 \\
& & Deep processing & -0.13 & 0.04 & -0.11 \\
& & Motivation/concentration problems & -0.07 & 0.03 & -0.09 \\
Student autonomy & \multirow{2}{*}{0.06} & Motivation/concentration problems & -0.17 & 0.03 & -0.16 \\
& & Personally interested & 0.16 & 0.04 & 0.12 \\
& & Certificate-oriented & -0.21 & 0.05 & -0.13 \\
& & Intake of knowledge & 0.13 & 0.04 & 0.11 \\
Interaction & \multirow{2}{*}{0.07} & Motivation/concentration problems & -0.11 & 0.02 & -0.14 \\
& & Cooperative learning & -0.08 & 0.02 & -0.11 \\
& & Lack of regulation & -0.08 & 0.02 & -0.11 \\
Differentiation & \multirow{2}{*}{0.05} & Motivation/concentration problems & -0.10 & 0.02 & -0.13 \\
& & Deep processing & -0.16 & 0.03 & -0.16 \\
& & Personally interested & 0.08 & 0.03 & 0.08 \\
Clarity of goals & \multirow{2}{*}{0.09} & Personally interested & 0.26 & 0.04 & 0.17 \\
& & Lack of regulation & -0.21 & 0.04 & -0.17 \\
Personalisation & 0.06 & Lack of regulation & -0.18 & 0.03 & -0.18 \\
& & Personally interested & 0.14 & 0.04 & 0.12 \\
\hline & & & &
\end{tabular}

scores are based on the discrepancy between perceptions and preferences, lower match scores of students with motivational and concentration problems could be because of lower perception scores, higher preference scores or a combination of both. Likewise, personally interested students could have better match scores because of higher perceptions, more moderate preferences or a combination of both. Therefore, we conducted some extra explorative (multiple regression) analyses on the relations between perception scores and learning-related student characteristics, and between the preference scores and students' characteristics.

Table 5 presents the results on the relations between perceptions and learningrelated characteristics. Results on relations between preference scores and learning-related characteristics are presented in Table 6. The amount of explained variance was on average 14\% for perceptions (ranging between 4 and 30\%) and around $19 \%$ for preferences (between 8 and $35 \%$ ). The variables of interest are printed in bold (personally interested) or underlined (motivation/concentration problems). It turned out that on the scales with positive relations between perception-preference match scores and personal interest (Table 4), also positive relations were found between perception scores and personal interest (for fascinating contents, student autonomy, clarity of goals, and personalisation; Table 5), but not for preference scores (Table 6). These findings indicate that higher perceptionpreference match scores of personally interested students are likely to originate from their more positive perceptions of the environment.

On the scales with negative relations between perception-preference match and motivation/concentration problems (Table 4), negative relations with perception scores were found on six scales (for fascinating contents, productive learning, 
Table 5. Significant regression weights $(p<0.01)$ of variables predicting perceptions.

\begin{tabular}{|c|c|c|c|c|c|}
\hline Dependent variable & $R^{2}$ & Independent variable(s) & $B$ & SE $B$ & $\beta$ \\
\hline \multirow[t]{3}{*}{ Fascinating contents } & 0.30 & Personally interested & 0.34 & 0.04 & 0.28 \\
\hline & & Motivation/concentration problems & -0.25 & 0.03 & -0.25 \\
\hline & & $\overline{\text { Construction and use of knowledge }}$ & 0.29 & 0.04 & 0.22 \\
\hline \multirow[t]{2}{*}{ Productive learning } & 0.15 & Stepwise processing & -0.27 & 0.04 & -0.19 \\
\hline & & Motivation/concentration problems & -0.17 & 0.04 & -0.14 \\
\hline \multirow[t]{6}{*}{ Integration } & 0.12 & $\overline{\text { Construction and use of knowledge }}$ & 0.20 & 0.04 & 0.18 \\
\hline & & Vocation-oriented & 0.13 & 0.03 & 0.14 \\
\hline & & Motivation/concentration problems & -0.09 & 0.02 & -0.11 \\
\hline & & Personally interested & 0.09 & 0.03 & 0.10 \\
\hline & & External regulation & 0.10 & 0.03 & 0.09 \\
\hline & & Vocation-oriented & 0.08 & 0.03 & 0.09 \\
\hline \multirow{3}{*}{ Student autonomy } & 0.06 & Personally interested & 0.12 & 0.03 & 0.12 \\
\hline & & Motivation/concentration problems & -0.08 & 0.03 & -0.10 \\
\hline & & $\overline{\text { Construction and use of knowledge }}$ & 0.11 & 0.04 & 0.10 \\
\hline \multirow[t]{2}{*}{ Interaction } & 0.19 & Cooperative learning & 0.21 & 0.02 & 0.28 \\
\hline & & Motivation/concentration problems & -0.12 & 0.02 & -0.16 \\
\hline Differentiation & 0.04 & External regulation & -0.12 & 0.04 & -0.10 \\
\hline \multirow[t]{4}{*}{ Clarity of goals } & 0.12 & Ambivalent & -0.16 & 0.04 & -0.13 \\
\hline & & Personally interested & 0.20 & 0.04 & 0.15 \\
\hline & & Lack of regulation & -0.14 & 0.04 & -0.12 \\
\hline & & External regulation & 0.14 & 0.05 & 0.09 \\
\hline \multirow[t]{5}{*}{ Personalisation } & 0.11 & Personally interested & 0.13 & 0.04 & 0.11 \\
\hline & & External regulation & 0.18 & 0.04 & 0.13 \\
\hline & & Lack of regulation & -0.13 & 0.03 & -0.13 \\
\hline & & Motivation/concentration problems & -0.08 & 0.03 & -0.08 \\
\hline & & $\overline{\text { Construction and use of knowledge }}$ & 0.12 & 0.04 & 0.09 \\
\hline
\end{tabular}

integration, interaction, student autonomy and personalisation; Table 5) and a positive relation to preference scores on one scale (i.e. student autonomy; Table 6). On the vast majority of the scales, however, lower perception-preference match scores of students with motivation/concentration problems seem to be because of lower perception scores, rather than to higher preference scores.

\section{Discussion and conclusions}

This study aimed to provide insight in students' perception-preference match with respect to their learning environment. For the first research question - to what degree do students' perceptions of their learning environment correspond with their preferences on eight characteristics of modern education? - the results show that students are least satisfied with the degree to which contents were fascinating for them, the clarity of goals, and the offered opportunities for student autonomy. Students clearly prefer all studied characteristics of modern education (Könings, Brand-Gruwel, and Van Merriënboer 2005), including fascinating content, productive learning, integration, student autonomy, interactive learning, clarity of goals and personalisation. The only exception is differentiation, which is not a popular characteristic of education for students. The desirability of most aspect of modern education is a very positive outcome, as it indicates congruence between the aims of educational designers and students, which is essential for optimal functioning of a learning environment (Elen and Lowyck 1999). 
Table 6. Significant regression weights $(p<0.01)$ of variables predicting preferences.

\begin{tabular}{|c|c|c|c|c|c|}
\hline Dependent variable & $R^{2}$ & Independent variable(s) & $B$ & SE $B$ & $\beta$ \\
\hline \multirow[t]{5}{*}{ Fascinating contents } & 0.23 & Construction and use of knowledge & 0.27 & 0.03 & 0.27 \\
\hline & & Deep processing & 0.14 & 0.03 & 0.14 \\
\hline & & Certificate-oriented & 0.11 & 0.02 & 0.10 \\
\hline & & Lack of regulation & 0.08 & 0.02 & 0.10 \\
\hline & & Keeping a good state of mind & 0.08 & 0.03 & 0.08 \\
\hline \multirow[t]{3}{*}{ Productive learning } & 0.21 & Stepwise processing & -0.58 & 0.04 & -0.41 \\
\hline & & Intake of knowledge & -0.21 & 0.04 & -0.16 \\
\hline & & External regulation & 0.13 & 0.05 & 0.08 \\
\hline \multirow{6}{*}{ Integration } & 0.29 & Construction and use of knowledge & 0.23 & 0.03 & 0.26 \\
\hline & & Deep processing & 0.14 & 0.03 & 0.15 \\
\hline & & Vocation-oriented & 0.07 & 0.02 & 0.10 \\
\hline & & Stimulating education & 0.07 & 0.02 & 0.10 \\
\hline & & Keeping a good state of mind & 0.07 & 0.02 & 0.08 \\
\hline & & Cooperative learning & 0.05 & 0.02 & 0.07 \\
\hline \multirow[t]{6}{*}{ Student autonomy } & 0.08 & Vocation-oriented & 0.09 & 0.02 & 0.12 \\
\hline & & Motivation/concentration problems & 0.08 & 0.02 & 0.12 \\
\hline & & $\overline{\text { Certificate-oriented }}$ & 0.15 & 0.03 & 0.15 \\
\hline & & Intake of knowledge & -0.10 & 0.03 & -0.13 \\
\hline & & Cooperative learning & 0.08 & 0.02 & 0.11 \\
\hline & & Fear of failure & -0.07 & 0.03 & -0.08 \\
\hline \multirow[t]{4}{*}{ Interaction } & 0.35 & Cooperative learning & 0.34 & 0.02 & 0.50 \\
\hline & & Construction and use of knowledge & 0.11 & 0.03 & 0.12 \\
\hline & & Vocation-oriented & 0.07 & 0.02 & 0.10 \\
\hline & & Stepwise processing & 0.07 & 0.02 & 0.08 \\
\hline \multirow[t]{4}{*}{ Differentiation } & 0.13 & Intake of knowledge & -0.24 & 0.03 & -0.21 \\
\hline & & Stepwise processing & -0.18 & 0.04 & -0.15 \\
\hline & & Construction and use of knowledge & 0.14 & 0.04 & 0.11 \\
\hline & & Vocation-oriented & -0.09 & 0.03 & -0.08 \\
\hline \multirow{3}{*}{ Clarity of goals } & 0.10 & Certificate-oriented & 0.18 & 0.03 & 0.18 \\
\hline & & External regulation & 0.11 & 0.03 & 0.13 \\
\hline & & Construction and use of knowledge & 0.09 & 0.03 & 0.11 \\
\hline \multirow[t]{5}{*}{ Personalisation } & 0.14 & Construction and use of knowledge & 0.16 & 0.03 & 0.17 \\
\hline & & Certificate-oriented & 0.13 & 0.03 & 0.13 \\
\hline & & Stimulating education & 0.08 & 0.02 & 0.10 \\
\hline & & Keeping a good state of mind & 0.10 & 0.03 & 0.11 \\
\hline & & Cooperative learning & 0.06 & 0.02 & 0.09 \\
\hline
\end{tabular}

Students do not perceive all those aspects as being present in their education. They do perceive enough integration, interaction, clarity of goals and personalisation in their lessons. However, we found that they deny seeing, for example, lots of room for student autonomy. This finding could be because students do not always have an accurate perception of teachers' intentions in education (Broekkamp 2003). For instance, a teacher might have the intention to be clear about learning goals, but if students do not pick up relevant signals from the teacher this does not have the intended effects. Another possible explanation is that the instructional design of the lessons is not yet as modern and innovative as it could be (Könings, Brand-Gruwel, and Van Merriënboer 2007a). Teachers experience practical problems that make it difficult to use new instructional methods or their persistent approaches to teaching may hinder a complete implementation of innovations (Könings, Brand-Gruwel, and Van Merriënboer 2007a). In addition to perceiving too little room for autonomy, 
students did not perceive fascinating contents, productive learning and differentiation. Together with high desirability of these aspects of education, these results show that students see ample room for improvement of the learning environment.

The second research question focused on how perception-preference match relates to learning-related student characteristics. The results show that motivational and affective subscales relate most clearly to perception-preference match: learning because of personal interest relates to a high perception-preference match, whereas reporting motivation/concentration problems is strongly linked to a low perceptionpreference match. Although earlier research has also shown relations with the other learning-related student characteristics, motivation and affective strategies appeared to be the most important variables in relation to perception-preference match (e.g. Eccles et al. 1993; Hardre and Reeve 2003; Ireson and Hallam 2005).

The found relations between variables, however, do not allow for any conclusions about the causal direction of found effects. Thus, do students become frustrated and lose motivation because of the education they follow? Or are they unhappy and do they attribute their negative feelings to school and the lessons? In daily life, a popular explanation is that because of puberty, many students do not value school because other things are more important for them. However, Roeser, Eccles, and Sameroff (2000) clearly distinguish between students for whom a low valuing of school is a marker for complex problems (e.g. poor motivation to learn, poor mental health, poor grades, affiliation with negative peers), and students who are just bored with their schooling. Other studies (Eccles et al. 1993) have also shown negative motivational consequences when the environment does not match well with the developmental needs and does not foster enough developmental growth. In a longitudinal study, Hardre and Reeve (2003) found that experiences in the classroom predict levels of motivation and students' intentions to persist or drop-out, indicating a causal relation from perception-preference match to motivation for learning.

Concluding, there is a genuine possibility that - at least part of - the students report motivation/concentration problems or low personal interest in learning because of characteristics of their current learning environment. This underlines the claim that education could be further improved by taking a closer look at students' perceptionpreference match. Because students prefer lessons that incorporate the characteristics of modern education more than currently perceived, their perspectives are worth to get a more prominent place in the design process of educational innovations.

A first theoretical implication is that motivational and affective student characteristics have to be considered as most important correlates to perceptionpreference match. Although other characteristics may be important as well, in this study personally interested motivational orientation and motivation/concentration problems were identified as most closely related to perception-preference match (in order, in a positive and a negative direction). Furthermore, students' perceptionpreference match was introduced as a dependent variable in our study. Wierstra et al. (1999) already described dissatisfaction as the discrepancy between perceptions and preferences, but it was not used before as a dependent variable. The current study shows that it is an important and informative additional construct when investigating students' perspectives on education.

A practical implication of this study is that, when listening to students' experiences and suggestions for improving lessons (e.g. Könings, van Zundert, Brand-Gruwel, and van Merriënboer 2007b), it is important to listen to all students. When a teacher asks students for their ideas - informally in the class situation or 
during a meeting on collaboratively redesigning lessons $-\mathrm{s} /$ he has to talk with a representative sample of the students in his/her class. Both satisfied and dissatisfied students have to be consulted and involved in redesigning lessons. Students with a low perception-preferences match should certainly not be excluded from such a discourse because their criticisms are unwelcome. Probably, these students will benefit most from the opportunity to contribute to the (re)design of their education. By listening to all students - also the more dissatisfied ones - the communication between students and teachers is likely to improve, which positively affects the learning climate in the class (Seidel and Shavelson 2007) and, ultimately, the learning performances of students.

A limitation of the current study is that the explained amount of variance in the analyses was rather low and there may have been capitalisation of chance because of conducting eight regression analyses. However, while applying a significance level of $p<0.01$, the results have still shown a clear pattern of variables that seem to be important. Another limitation is that students are asked to report on their perceptionpreference match with respect to the lessons in their current school year. This provides only general measures, independent of specific subject matter or teacher. Investigating the perception-preference match at a micro-level could be the focus of future research. Additionally, future investigations should give more clarity about the causal relations between perception-preference match and motivational and affective variables. It would be highly interesting to examine whether raising students' perceptionpreference match by educational redesign could improve motivation and decrease motivation/concentration problems. Another interesting point for future research starts with our finding of students' resistance for differentiation. As differentiating education to adapt to individual needs seems crucial for optimising the perceptionpreference match, underlying causes for this resistance have to be investigated.

To conclude, this study has shown students' perception-preference match can give clear indications for which aspects of lessons could be improved. As students consider almost all characteristics of modern education as desirable, meeting student preferences could contribute to more effective education. Additionally, the perception-preference match appeared clearly related to students' motivation and affective strategies. This study does not allow conclusions about the causal direction, but the available literature seems to indicate bidirectional relations. Improving education by accounting for the match between students' perceptions and preferences about education is thus likely to improve motivation besides a feasible effect on the quality of education. This supports our claim that teachers and designers need to take students' perception-preference match more seriously into account.

\section{Acknowledgements}

This research was supported by the Netherlands Organisation for Scientific Research (NWO) under project number 411-01-052.

\section{References}

Bong, M. 2005. Within-grade changes in Korean girls' motivation and perceptions of the learning environment across domains and achievement levels. Journal of Educational Psychology 97: 656-72.

Broekkamp, H. 2003. Task demands and test expectations: Theory and empirical research on students' preparation for a teacher-made test. PhD dissertation, University of Amsterdam. 
Burke, C. 2007. The view of the child: Releasing 'visual voices 'in the design of learning environments. Discourse: Studies in the Cultural Politics of Education 28: 359-72.

Campbell, J., D. Smith, G. Boulton-Lewis, J. Brownlee, P.C. Burnett, S. Charrington, 2001. Students' perceptions of teaching and learning: The influence of students' approaches to learning and teachers' approaches to teaching. Teachers and Training: Theory and Practice 7: $173-87$.

Cook-Sather, A. 2001. Unrolling roles in techno-pedagogy: Toward new forms of collaboration in traditional college settings. Innovative Higher Education 26: 121-39.

Dart, B., P. Burnett, G. Boulton-Lewis, J. Campbell, D. Smith, and A. McCrindle. 1999. Classroom learning environments and students' approaches to learning. Learning Environments Research 2: 137-56.

Dart, B.C., P.C. Burnett, N. Purdie, G. Boulton-Lewis, J. Campbell, and D. Smith. 2000. Students' conceptions of learning, the classroom environment, and approaches to learning. The Journal of Educational Research 93: 262-70.

Donaldson, M. 1978. Children's mind. London: Fontana.

Doyle, W. 1977. Paradigms for research on teacher effectiveness [5]. In Review of research in education, ed. L.S. Schulman, 163-97. Itasca, IL: F.E. Peacock.

Eccles, J.S., A. Wigfield, C. Midgley, D. Reuman, D. Mac Iver, and H. Feldlaufer. 1993. Negative effects of traditional middle schools on students' motivation. The Elementary School Journal 93: 553-74.

Elen, J., and J. Lowyck. 1999. Metacognitive instructional knowledge: Cognitive mediation and instructional design. Journal of Structural Learning and Intelligent Systems 13: 145-69.

Entwistle, N.J., and P. Ramsden. 1983. Understanding student learning. London: Croom Helm.

Entwistle, N., and H. Tait. 1990. Approaches to learning, evaluations of teaching, and preferences for contrasting academic environments. Higher Education 19: 169-94.

Hardre, P.L., and J. Reeve. 2003. A motivational model of rural students' intentions to persist in, versus drop out of, high school. Journal of Educational Psychology 95: 347-56.

Hijzen, D., M. Boekaerts, and P. Vedder. 2007. Exploring the links between students' engagement in cooperative learning, their goal preferences and appraisals of instructional conditions in the classroom. Learning and Instruction 17: 673-87.

Ireson, J., and S. Hallam. 2005. Pupils' liking for school: Ability grouping, self-concept and perceptions of teaching. British Journal of Educational Psychology 75: 297-311.

Kershner, R., and P. Pointon. 2000. Children's views of the primary classroom as an environment for working and learning. Research in Education 64: 64-77.

Könings, K.D., S. Brand-Gruwel, and J.J.G. van Merriënboer. 2005. Towards more powerful learning environments through combining the perspectives of designers, teachers and students. British Journal of Educational Psychology 75: 645-60.

Könings, K.D., S. Brand-Gruwel, and J.J.G. van Merriënboer. 2007a. Teachers' perspective on innovations: Implications for educational design. Teaching and Teacher Education 23: 985-97.

Könings, K.D., M.J. van Zundert, S. Brand-Gruwel, and J.J.G. van Merriënboer. 2007b. Participatory design in secondary education: Its desirability and feasibility according to teachers and students. Educational Studies 33: 445-65.

Könings, K.D., S. Brand-Gruwel, J.J.G. van Merriënboer, and N. Broers. 2008. Does a new learning environment come up to students' expectations? A longitudinal study. Journal of Educational Psychology 100: 535-48.

Levy, J., P. Den Brok, T. Wubbels, and M. Brekelmans. 2003. Students' perceptions of interpersonal aspects of the learning environment. Learning Environments Research 6: 5-36.

Luyten, L., J. Lowyck, and F. Tuerlinckx. 2001. Task perception as a mediating variable: A contribution to the validation of instructional knowledge. British Journal of Educational Psychology 71: 203-23.

Markopoulos, P., and M. Bekker. 2003. Interaction design and children. Interacting with Computers 15: 141-9.

Ministerie van Onderwijs, Cultuur en Wetenschap (n.d.). Dossier Tweede Fase [Dossier Second Phase]. Retrieved 1 August 2005, from http://www.minocw.nl/tweedefase/factsheet.html

Norman, D.A. 1986. Cognitive engineering. In New perspectives on human-computer interaction, ed. D.A. Norman and S.W. Draper, 31-62. Hillsdale, NJ: Lawrence Erlbaum Associates.

Norman, D.A. 1988. The psychology of everyday things. New York: Basic Books. 
Onderwijsinspectie [Dutch Inspection of Education]. 2006. Opbrengstenkaarten [Achievement cards]. Retrieved 15 December 2006, from http://www.onderwijsinspectie.nl/

Ozkal, K., C. Tekkaya, J. Cakiroglu, and S. Sungur. 2009. A conceptual model of relationships among constructivist learning environment perceptions, epistemological beliefs, and learning approaches. Learning and Individual Differences 19: 71-9.

Picarelli, A., M. Slaats, P.A.J. Bouhuijs, and J.D. Vermunt. 2006. Leerstijl en leeromgeving in het Voortgezet Onderwijs: Nederland en Vlaanderen vergeleken [Learning style and learning environment in secondary education: The Netherlands and Flanders compared]. Pedagogische Studiën 83: 139-55.

Pintrich, P.R., and B. Schrauben. 1992. Students' motivational beliefs and their cognitive engagement in classroom academic tasks. In Student perceptions in the classroom, ed. D.H. Schunk and J.L. Meece, 287-306. Hillsdale, NJ: Lawrence Erlbaum Associates.

Pratt, D.D. 1992. Conceptions of teaching. Adult Education Quarterly 42: 203-20.

Roeser, R.W., J.S. Eccles and A.J. Sameroff. 2000. School as a context of early adolescents' academic and social-emotional development: A summary of research findings. The Elementary School Journal 100: 443-71.

Schwinger, M., R. Steinmayr, and B. Spinath. 2009. How do motivational regulation strategies affect achievement: Mediated by effort management and moderated by intelligence. Learning and Individual Differences 19: 621-7.

Seidel, T., and R.J. Shavelson. 2007. Teaching effectiveness research in the last decade: Role of theory and research design in disentangling meta-analysis results. Review of Educational Research 77: 454-99.

Smyth, J., and L. Fasoli. 2007. Climbing over the rocks in the road to student engagement and learning in a challenging high school in Australia. Educational Research 49: 273-95.

Steinmayr, R., and B. Spinath. 2009. The importance of motivation as a predictor of school achievement. Learning and Individual Differences 19: 80-90.

Stuurgroep Profiel Tweede Fase Voortgezet Onderwijs. 1995. Verschil moet er zijn [There should be a difference]. The Hague: Stuurgroep Profiel Tweede Fase Voortgezet Onderwijs.

Trigwell, K., and M. Prosser. 1991. Improving the quality of student learning: The influence of learning context and student approaches to learning on learning outcomes. Higher Education 22: 251-66.

Tsai, C.C. 2000. Relationships between student scientific epistemological beliefs and perceptions of constructivist learning environments. Educational Research 42: 193-205.

Vermetten, Y.J., J.D. Vermunt, and H.G. Lodewijks. 2002. Powerful learning environments? How university students differ in their response to instructional measures. Learning and Instruction 12: 263-84.

Vermunt, J.D.H.M. 1992. Leerstijlen en sturen van leerprocessen in het hoger onderwijs: Naar procesgerichte instructie in zelfstandig denken [Learning styles and regulations of learning in higher education: Towards process-oriented instruction in autonomous thinking]. Amsterdam/Lisse: Swets and Zeitlinger.

Vermunt, J.D. 1998. The regulation of constructive learning processes. British Journal of Educational Psychology 68: 149-71.

Vermunt, J.D., P.A.J. Bouhuijs, and A. Picarelli. 2003. Vragenlijst Leerstijlen voor het Voortgezet Onderwijs (VLS-VO) [Inventory of Learning Styles for Secondary Education (ILS-SE)]. Maastricht University: Expertise Center Active Learning.

Vermunt, J.D., and Y.J. Vermetten. 2004. Patterns in student learning: Relationships between learning strategies, conceptions of learning, and learning orientations. Educational Psychology Review 16: 359-84.

Wierstra, R.F.A., G. Kanselaar, J.L. van der Linden, and H.G.L.C. Lodewijks. 1999. Learning environment perceptions of European university students. Learning Environments Research 2: 79-98. 